\title{
Determination of Displacement in a Loaded Wooden Chair by Using Digital Image Correlation
}

\section{Određivanje pomaka opterećenoga drvenog stolca primjenom korelacije digitalne slike}

\author{
Preliminary paper • Prethodno priopćenje \\ Received-prispjelo: 12. 3. 2014. \\ Accepted-prihvaćeno: 20. 5. 2015. \\ UDK: $630 * 836 ; 630 * 812.7 ; 630 * 832.282$ \\ doi:10.5552/drind.2015.1411
}

\begin{abstract}
SAŽETAK - The subject of the research is a ready to assemble (RTA) chair constructed of plywood by a CNC machine. The standard test of seat and back of the chair according to the Czech Standard CSN EU 1728 was supplemented with an optical method of digital image correlation (DIC). The aim of the research was to discover mechanical principles of the construction and to develop a methodology of standardized furniture testing. Results of experimental measurement show the response of the chair construction in a form of displacement fields, strain fields, charts and vectors depicting displacement of the observed points. The results can be used to improve mechanical properties of the construction, as well as to develop a shape of the product or specific parts of the product. Besides furniture testing laboratories and research institutes, engineers from development departments of furniture making companies or industrial designers can easily use the presented method.
\end{abstract}

Key words: standard furniture testing, digital image correlation, chair, plywood, CNC

SAŽETAK • Predmet istraživanja bio je stolac spreman na sklapanje (RTA), izrađen od uslojenog drva na CNC stroju. Standardni test sjedala i naslona stolca prema češkom standardu CSN EU 1728 dopunjen je optičkom metodom korelacije digitalne slike (DIC). Cilj istraživanja bio je otkriti mehanička načela konstrukcije te obogatiti metodologiju standardiziranog ispitivanja namještaja. Rezultati eksperimentalnih mjerenja prikazuju reakciju konstrukcije stolca u obliku polja pomaka, polja naprezanja te grafikona i vektora koji predočuju pomake promatranih točaka. Rezultati se mogu iskoristiti za poboljšanje mehaničkih svojstava konstrukcije, kao i za razvoj oblika proizvoda ili ispitivanih dijelova. Osim u laboratoriju za ispitivanje namještaja ili u istraživačkim institutima, prikazanom se metodom lako mogu koristiti inženjeri razvojnih odjela u tvrtkama za proizvodnju namještaja ili industrijski dizajneri.

Ključne riječi: standardno ispitivanje namještaja, korelacija digitalne slike, stolac, ploča od uslojenog drva, CNC stroj

\footnotetext{
${ }^{1}$ Authors are assistant, Ph.D. student, assistant and assistant at Faculty of Forestry and Wood Technology, Mendel University in Brno, Brno, Czech Republic.

${ }^{1}$ Autori su asistent, doktorand, asistent i asistent Mendelova sveučilišta u Brnu, Fakultet šumarstva i drvne tehnologije, Brno, Republika Češka.
} 


\section{INTRODUCTION}

\section{UVOD}

Information technology development and industry automation resulted in the development of $\mathrm{CNC}$ technologies, nowadays also used in furniture manufacturing. RTA furniture made of wood composites by $\mathrm{CNC}$ machines is the most often serially manufactured furniture. While the furniture has been produced for more than twenty years, experience with constructing it and with its strength properties is limited. Until recently, the trial and error approach was the only way to research the methods of development of furniture and wooden products. Development of technologies, new materials and informatics not only in production and marketing, but also in furniture design, brings about many methods that allow engineers and designers to adopt new approaches to their work. Despite the fact that standardized furniture testing, e.g. according to European Standards (EN), is not compulsory for producers in most cases, it is commonly implemented. Numerical simulations have been applied by furniture industry in a limited way so far (e.g. Mirra Office Chair; Larder and Wiersma, 2007). However, they are supported by research rather significantly. From a large number of studies, we would like to mention the research on behaviour of constructions of upholstered furniture (Smardzewski and Prekrat, 2009), sitting furniture (Prekrat et al., 2012; Horman et al., 2010; Smardzewski and Gawroński, 2003), box-type furniture (Nicholls and Crisan, 2002; Tankut et al., 2012), bed (Koňas, 2008), desk (Novotný et al., 2011), as well as the research on behaviour of wood product joints (Mihailescu, 2003; Černok et al., 2004; Prekrat and Smardzewski, 2010; Serrano and Enquist, 2010). The issue of strength design of furniture and various research methods is rather comprehensively described by Eckelman (2003), Smardzewski (2004) and Joščák (1999).

Although optical research methods are relatively well described and applied in other industries, they are still rare in furniture making and logging. The issue of Digital Image Correlation (DIC) methodology in relation to a shape, and deformation measurement is described e.g. by Sutton (2008) or Cintrón and Saouma (2008). Nestorović et al. (2011) employed DIC (3D) and numerical simulation to define material properties of veneer composite structure laminate, analysing a chosen shell of a chair. Smardzewski et al. (2008) analysed nonlinear behaviour of polyurethane furniture foams combining experimental testing, DIC measurement and numerical modelling. Also Enquist (2005) applied 3D DIC measurement for different purposes in furniture design and material testing. Miyauchi et al. (2006) analysed strain distributions of wooden dovetail joints using DIC. Also Masuda and Tabata (2000) combined DIC and numerical simulation (FEM) when testing pinned joints in wood under tension load. Betts et al. (2010) applied DIC to locate a neutral axis in wood beams strained by bending. Muszyński et al. (2002) employed DIC to research wood deformations with an axial creep test under varying climate conditions. Besides DIC, there are also other optical methods used in research and development of wood products, e.g. optical triangulation measuring the quality of surfaces (Costa, 2012) and precision of production against 3D models, laser vibrometers used for testing mechanical characteristics of furniture connections (Weyrauch et al., 2013), speckle pattern interferometers used for testing deformation of wooden joints (Umezaki et al., 2004) or photo tensometers used for testing gluing strength of wood joints (Mihulja et al., 2008).

The main objective of this study is to assess the mechanical behaviour of RTA chair constructed of plywood using an optical method based on digital image correlation. Another goal is to develop the methodology of standardized furniture testing so that it can also be used in research and development of furniture construction - industrial products.

\section{MATERIALS AND METHODOLOGY} 2. MATERIJAL I METODE

The chair was created parametrically in environment modelling of the CAD and CAM program, with dimensions 900 by 490 by $430 \mathrm{~mm}$. It was made by a CNC machining centre (with a nesting table) of $12 \mathrm{~mm}$ thick birch (Betula pendula) plywood, with integrated dovetail not-glued joints - RTA furniture. Similar principles of constructing furniture based on mass production were described e.g. by Oh et al (2006). The chair was assembled from six parts. It was designed as selflocking (Figure 1a).

The chair construction was mechanically loaded in an accredited furniture testing laboratory according to the Czech Standard CSN EN 1728, Article No. 6.4 - Static strain test of a seat and back of a chair.

A universal pneumatic testing device was set up according to the template (Figure 1) and design. The device was loaded to the seat with the force of $1300 \mathrm{~N}$ and to the back with the force of $450 \mathrm{~N}$ in 10 cycles, from P1 and P2 points determined by the loading diagram (Figure 2 and Article 5.2 of the Standard). To prevent the chair from moving on the floor, it was supported with adjustable stops. Afterwards, the values of displacement in the horizontal and vertical direction for P1 - P6 points were assessed.

Experimental optical measurement was carried out by the DSLR (Digital Single-Lens Reflex) camera Nikon D5100 (16Mpix resolution) and Nikkor $50 \mathrm{~mm}$ F1.8 AF-S lens, which were set perpendicularly to the examined surface - the side frame of the chair. To achieve constant intensity of the recorded surface image, it was necessary to keep stable lighting conditions within image acquisition. For this purpose, the examined surface of the chair construction was lightened by a pair of diffuse lights. The frequency of recording was set up to $1 \mathrm{fps}$, the bit depth of images was 8-bit (256 shades of grey). 8-bit images are necessary for further processing and for computing the displacement fields. The open-source tethering software DigiCamControl (by Duka, I.), connected to the DSLC camera using the 


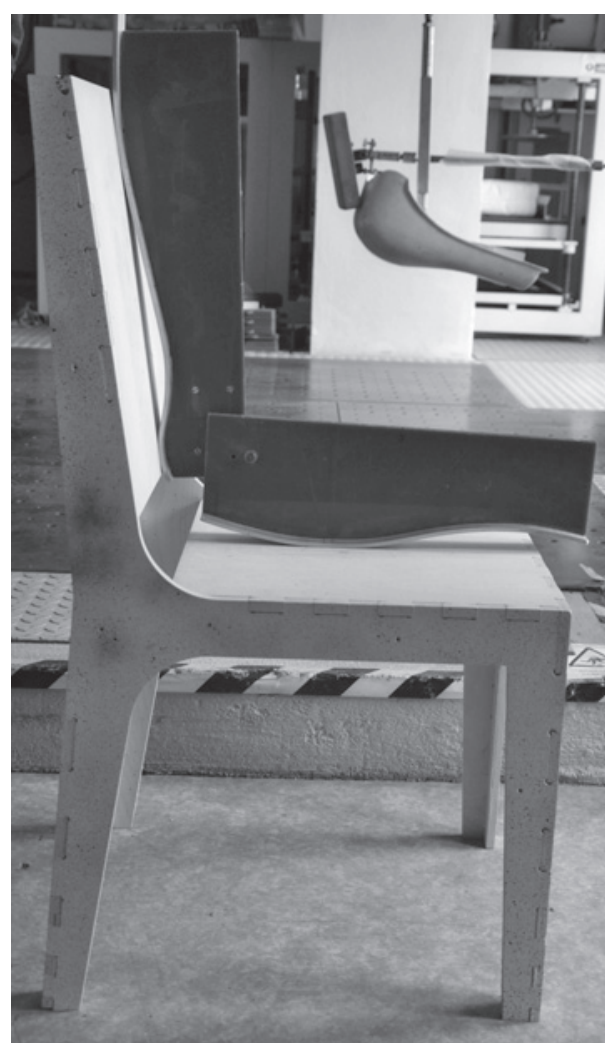

a.

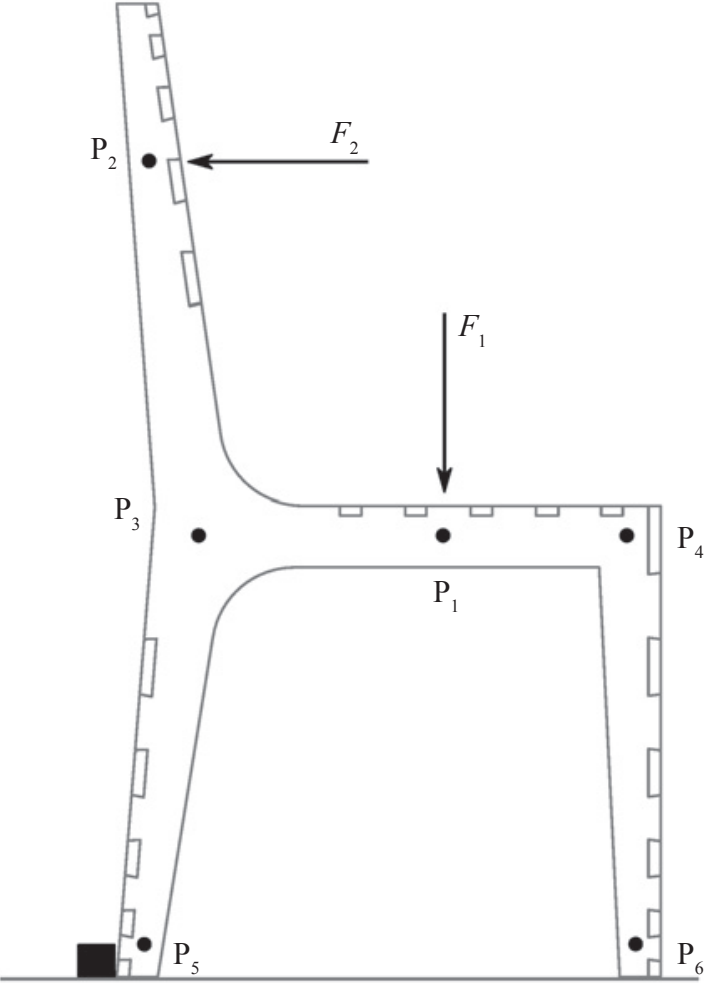

b.

Figure 1 a) Chair construction and template for determination of straining points $\mathrm{P} 1$ and $\mathrm{P} 2$, b) Scheme of experimental chair testing with P1 - P6 points

Slika 1. a) Konstrukcija stolca i predložak za određivanje točaka deformacije P1 i P2, b) shema eksperimentalnog ispitivanja stolca s označenim točkama od P1 do P6

USB port, was used to transfer data to a mobile PC station. Correlation computation of displacement and strain fields was carried out in the Vic-2D (by Correlated Solutions Inc.) program. Motion tracking of P1 - P6 points was carried out in the open-source program Blender (by Blender Foundation) and verified subsequently by the Vic-2D program. To guarantee the valid computation by the DIC method, it is necessary to cover the recorded surfaces with (ideally) a two-component contrasting colour (e.g. black and white) before testing. To fulfil this condition, a spray system was used from the distance, which provided speckles of recommended size of $3-6$ pixels (Sutton et al., 2009).

\section{RESULTS AND DISCUSSION}

\section{REZULTATI I RASPRAVA}

The first goal of the work was to compute the displacement fields on the chair side frame using the DIC method. The result is shown in Figure 2 and 3, where the back and the seat are in the second cycle of experimental testing (image No. 20). As it can be seen, the DIC computation brought reliable results based both on quantitative (standard deviation was lower than 0.05 ) and qualitative evaluation (displacement contours follow mechanical behaviour assumptions resulting from a loading mode). The ultimate value of horizontal displacement was observed at the top of backrest ( $u=3.92 \mathrm{~mm}$, Fig. 2) and the ultimate value of vertical displacement was observed at the front leg $(v=1.185$ $\mathrm{mm}$, Figure 3).

The next step in the analysis was to look at the strain fields computed from displacements. The strain field in horizontal direction $\left(\varepsilon_{x x}\right)$ is shown in Figure 4; the vertical strain component $\left(\varepsilon_{y y}\right)$ is shown in Figure 5 (also for image No. 20). The results indicate that vertical strain is the highest in the dovetail connections on top of the chair seat. Nonetheless, its highest absolute strain did not exceed $\sim 0.3 \%$, so we can affirm that all strains occurring there are elastic - below the proportional limit of all possible loading modes in wood and birch plywood (Bodig and Jayne, 1993; Wood Handbook, 2010). The horizontal strain is the highest in the backrest dovetail connections and its maximal absolute value is $\sim 1.56 \%$. This value is often measured above the proportional limit, so the question is whether plastic strain occurred or not. A detailed visual analysis of the connection indicated that the plastic strain most likely did not occur - the fibres of surface ply did not fail in any mode.

The reason why such high strains were obtained is that the computed strains at the connection interferences might be influenced by their geometric intolerances. It means that the virtual strain gages used for computing consider the gap between connection parts as solid parts of the chair, i.e. gaps are considered as parts of the applied stochastic colour pattern. Three fundamental findings resulted from that: a) it is neces- 


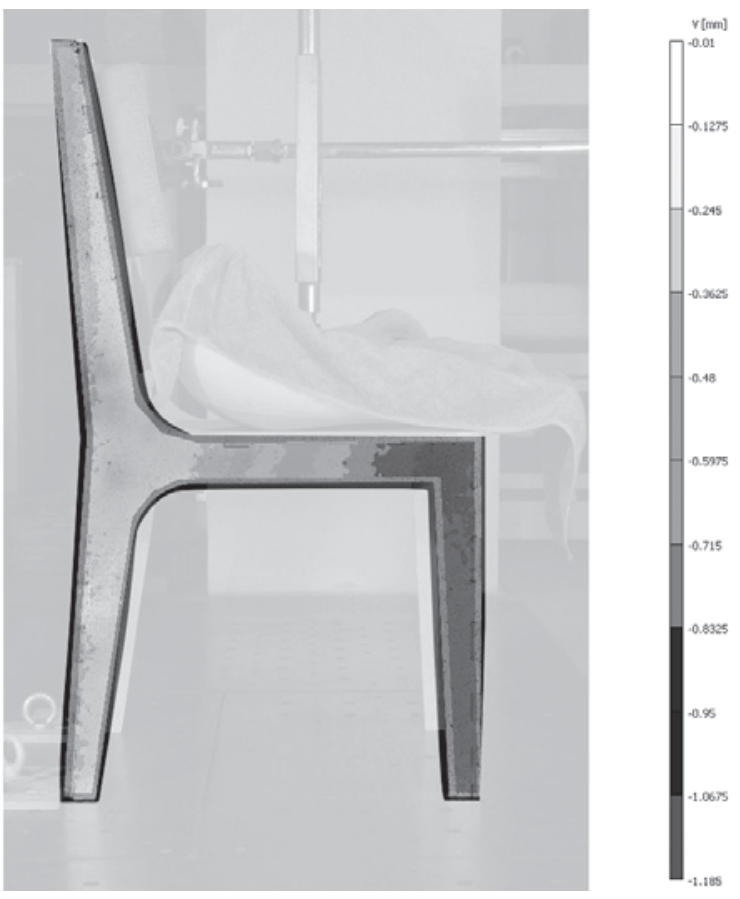

Figure 2 Horizontal displacement field, mm (for image No. 20) Slika 2. Područje horizontalnog pomaka, mm (za prikaz broj 20)

sary to analyse the dovetail connection from closer distance in greater detail, which would bring more information on strains in connection parts themselves and contact (nonlinear) behaviour; b) the strains obtained around the connections with bigger geometric intolerances should be analysed carefully to avoid errors; c) obtained displacements are reliable and not negatively influenced by virtual gages since they are computed beforehand from pixel moves. Therefore, the chosen acquisition distance is appropriate for kinematic assessment of the chair and brings a new perspective (2D data) on furniture testing.

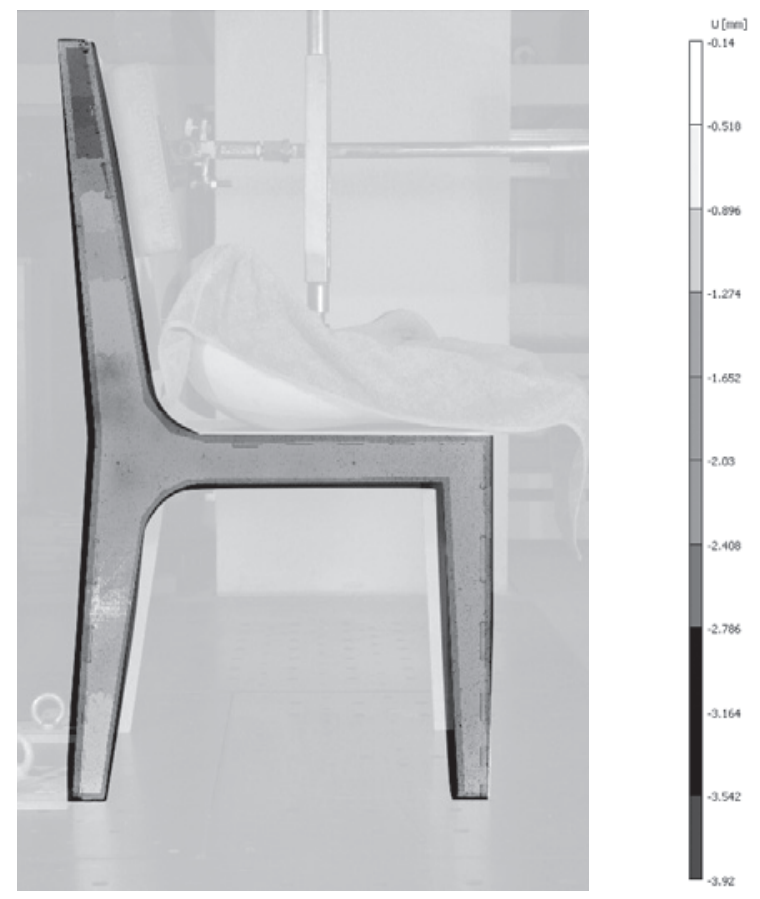

Figure 3 Vertical displacement field, mm (for image No. 20) Slika 3. Područje vertikalnog pomaka, mm (za prikaz broj 20)

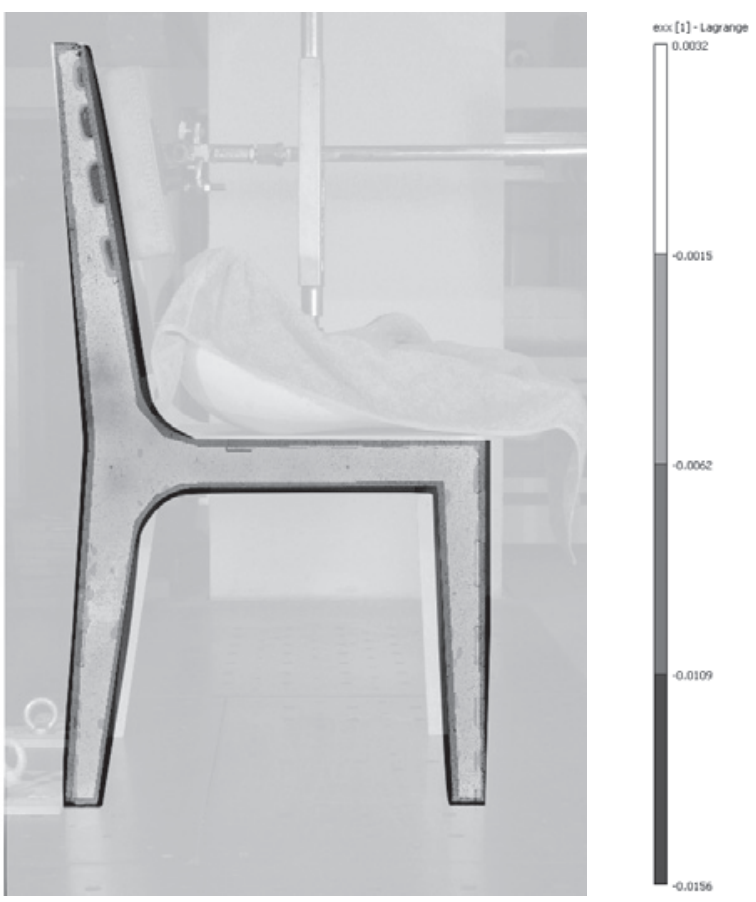

Figure 4 Strain field in horizontal direction $\left(\varepsilon_{x x}\right)$

Slika 4. Područje naprezanja u horizontalnom smjeru $\left(\varepsilon_{x x}\right)$

Displacement of observed nodal points is shown by charts in Figures $6-11$. Ten loading cycles in the seat and the back are significant in all charts $(1$ cycle 12 images). The following differences in maximum and minimum values of deviations (displacement) related to the observed points are of our interest. The most noticeable displacement was achieved in the horizontal direction (the $X$ axis), especially in $\mathrm{P} 2$ point (the back of the chair). The value achieved was approximately $6 \mathrm{~mm}$ (Figure 7). The displacement shows that, compared to the other observed parts of the construction, the back of the chair is relatively flexible.

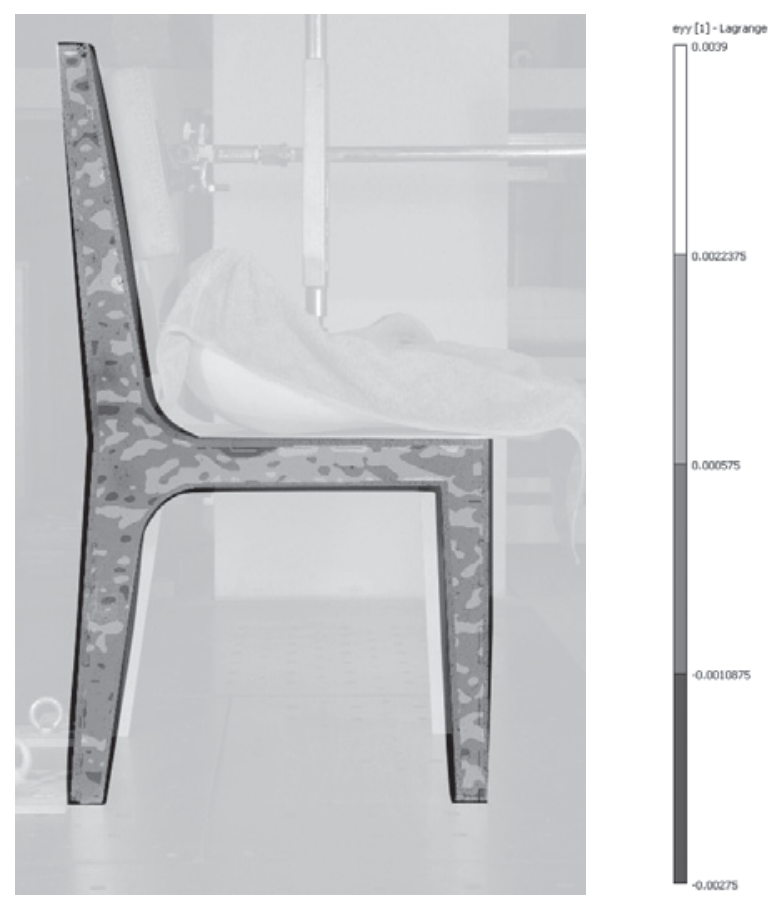

Figure 5 Strain field in vertical direction $\left(\varepsilon_{y v}\right)$

Slika 5. Područje naprezanja u vertikalnom smjeru $\left(\varepsilon_{x x}\right)$ 
The result is similar to the outcome obtained by Enquist (2005) within his research. The second highest value in the horizontal direction was measured in P3 point (connection of the seat and the back; approximately $2.6 \mathrm{~mm}$ (Figure 8 ). Nearly the same value of displacement in both directions was measured in points $\mathrm{P} 1$ (the seat) and P4 (connection of the seat and the front leg); in the $X$ axis approximately $2.5 \mathrm{~mm}$, in the $Y$ axis $1 \mathrm{~mm}$ (Figures 6 and 9). The most noticeable displacement in the vertical direction was measured in P6
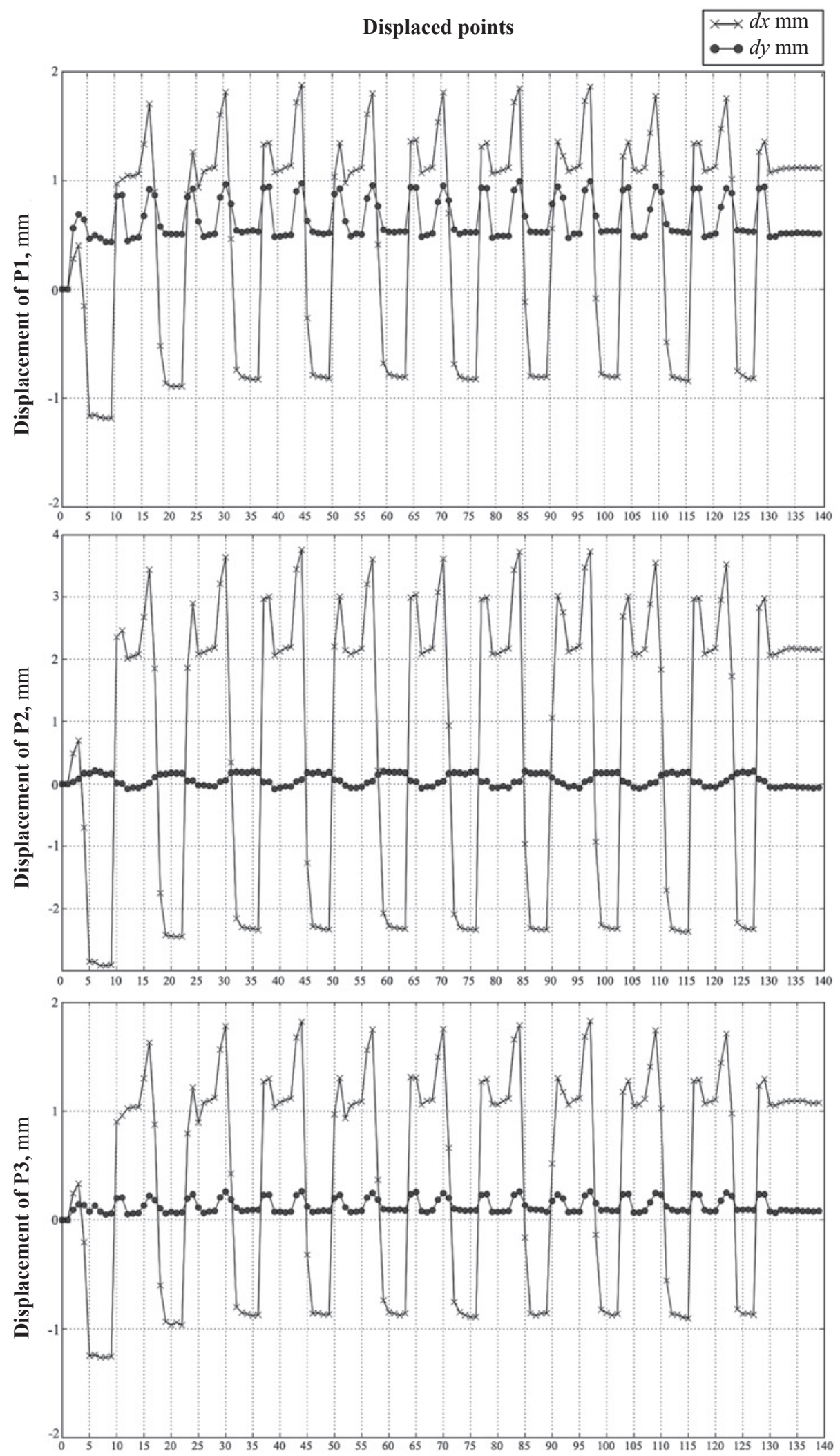

Sequence, \#

Figures 6-8 Charts showing displacement of P1 - P3 points in horizontal and vertical direction (axis $X$ and $Y$ in millimetres) Slike 6. - 8. Dijagrami pomaka u točkama $\mathrm{P} 1$ do $\mathrm{P} 3$ u horizontalnome i vertikalnom smjeru (osi $X$ i $Y$ u milimetrima) 

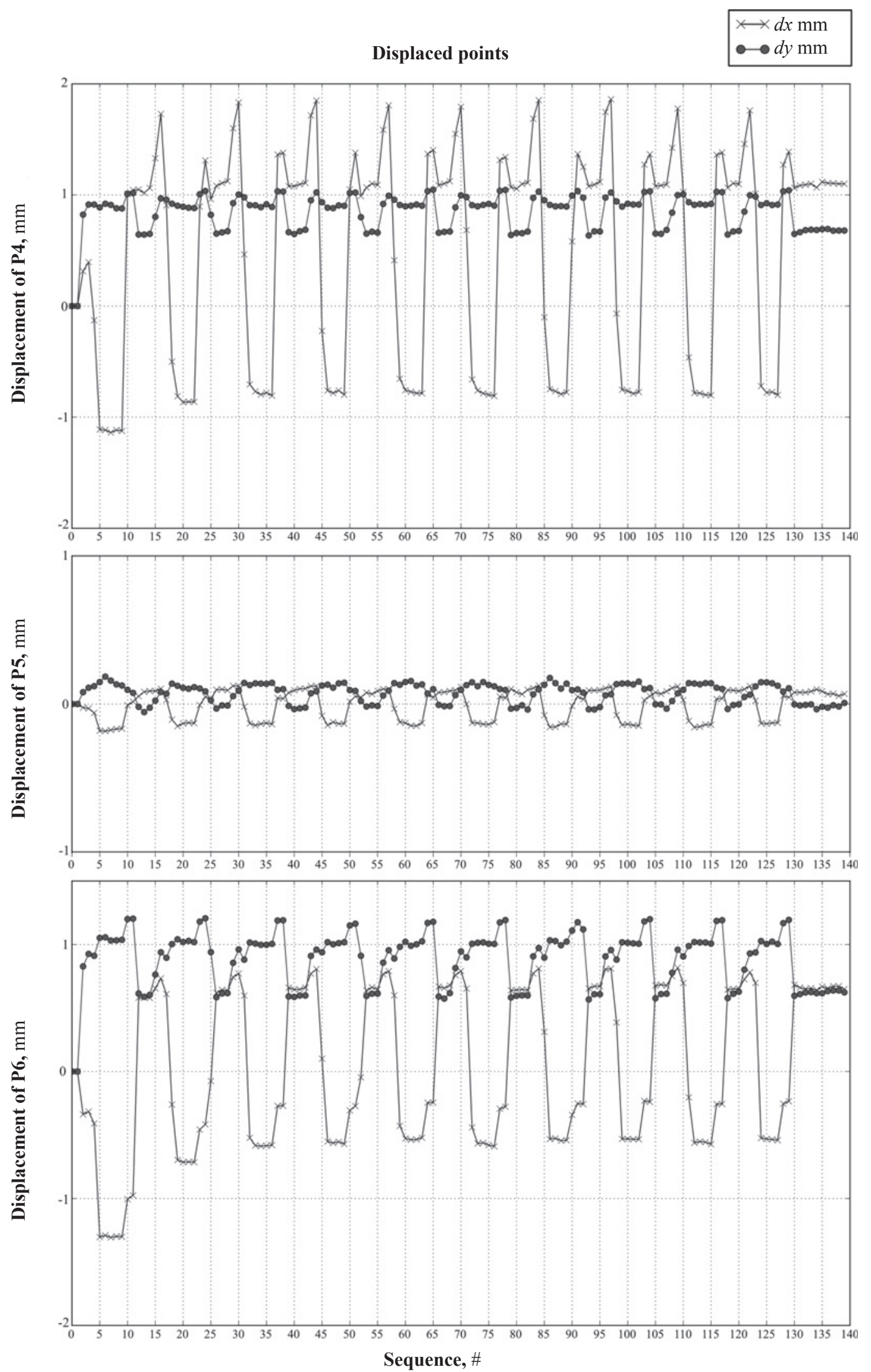

Figures 9 - 11 Charts showing displacement of P4 - P6 points in horizontal and vertical direction (axis $X$ and $Y$ in millimetres) Slike 9. - 11. Dijagrami pomaka u točkama od P4 do P6 u horizontalnome i vertikalnom smjeru (osi $X$ i $Y$ u milimetrima)

point (front leg); approximately $1.2 \mathrm{~mm}$ (Figure 11). Considering the position on the fixed pad, the displacement should be considerably lower (similarly as in P5 point, Figure 10). However, as the flat pack construction was the subject of the research, the effect was most likely caused by a small inaccuracy occurred when the chair was assembled. One more inaccuracy probably appeared when the chair was placed into the testing device - the front legs of the chair were set a bit imprecisely. Due to absence of stops at the front legs, dis- 


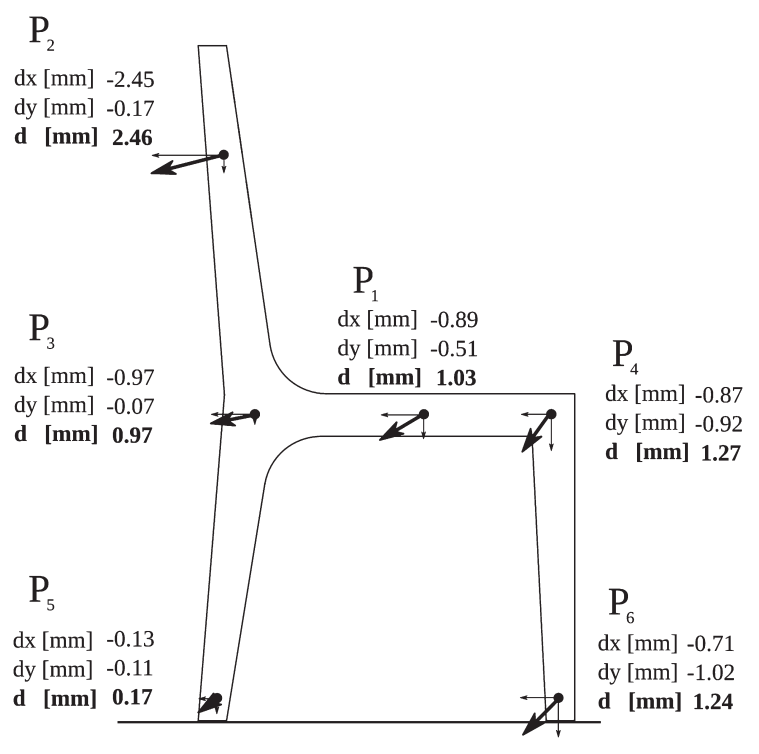

Figure 12 Vectors of displacement of the chosen points occurred within construction straining (for image No. 20) Slika 12. Vektori pomaka izabranih točaka stolca u kojima se pojavljuju deformacije konstrukcije

placement in the horizontal direction in P6 point was higher; approximately $2 \mathrm{~mm}$. The charts offer a possibility of comparing the chosen points of a construction or similar constructions (e.g. different prototypes of a product), as well as a possibility of testing the constructions durability when the number of cycles reaches thousands and fatigue of material and joints often occurs.

Final vectors of the displacement of all observed points in the second testing cycle (image No. 20) are shown in Figure 12. Directions of the vectors are similar but the obtained values are considerably lower (seven or eight times) than values of vectors measured by Enquist testing a chair with armrests. It is possible to say that our chair is stiffer (lower deflections) in bending than the one tested by Enquist (2005). Different construction of the chairs explains the difference in measured values. The chair tested by Enquist (2005) can be considered as a rod construction (of massive wood) with mortise and screw joints. The construction of the chair tested in this research is a plate type (of plywood) with dovetail joints, which usually reaches higher values of load capacity and solidity.

\section{CONCLUSION}

\section{ZAKLJUČAK}

The results based on measured experimental data can be summed up as follows:

- The tested chair construction shows the highest displacement in the back;

- The tested chair construction shows the largest strain in dovetail connections between the back and the side and between the seat and the side;

- The maximum deviation of the observed surface was detected in P2 point (the back of the chair);
- Individual load cycles are recognizable in the charts of the point displacement;

- The final vectors directions of the tested chair displacement are similar to the chair tested by Enquist (2005). Values of the final vectors related to the tested chair are considerably lower than values of the chair tested by Enquist (2005);

Considering the method applied, it is possible to say that the DIC can be easily used for and applied to furniture testing due to its relative simplicity and low requirements on devices used, undemanding data processing and assessment carried out by accredited laboratories or research institutes. Development departments of furniture making companies can apply the methodology to increase their competitiveness and innovation potential. By means of deeper analysis of data, it is possible to detect badly dimensioned construction connections or to optimize the construction in terms of shape or used materials.

\section{Acknowledgement - Zahvala}

The research was supported by the Internal Grant Agency of the Faculty of Forestry and Wood Technology, Mendel University in Brno - within the development project IGA No. 57/2013.

\section{REFERENCES}

\section{LITERATURA}

1. Betts, C. A.; Miller, T. H.; Gupta, R., 2010: Location of the neutral axis in Wood Beams: A preliminary study. Wood Material Science and Engineering, 5: 173-180. http://dx.doi.org/10.1080/17480272.2010.500060

2. Bodig, J.; Jayne, B. A., 1993: Mechanics of wood and wood composites. Malabar, Krieger Publish. Comp., p. 712.

3. Cintrón, R.; Saouma, V., 2008: Strain measurements with the Digital Image Correlation system Vic-2D. Department of Civil Environmental and Architectural Engineering, University of Colorado, Boulder, Colorado, p. 23.

4. Costa, M. F. M., 2012: Optical triangulation-based microtopographic inspection of surfaces. Sensors, 12: 4399-4420. http://dx.doi.org/10.3390/s120404399

5. Černok, A.; Joščák, P.; Lang, M., 2004: Výpočtový model kolíkového spoja. Nábytok 2004, Faculty of Wood Technolgy, Technical University in Zvolen, 12 p.

6. Eckelman, C., 2003: Product engineering and strength design of furniture. Purdue University, West Lafayette, Indiana, p. 204.

7. Enquist, B., 2005: Use of optical measurement techniques in furniture design. Department of Architecture, Chalmers University of Technology, Göteborg, Sweden, p. 13.

8. Horman, I.; Hajdarević, S.; Martinović, S.; Vukas, N., 2010: Numerical analysis of stress and strain in a wooden chair. Drvna industrija, 61 (3): 151-158.

9. Joščák, P., 1999: Pevnostné navrhovanie nábytku. Faculty of Wood Technolgy, Technical University in Zvolen, 246 p.

10. Koňas, P., 2006: Finite element model of the bed. Acta Universitatis Agriculturae et Silviculturae Mendelianae Brunensis, LIV (2): 67-72. http://dx.doi.org/10.11118/actaun200654020067

11. Larder, L.; Wiersma, J., 2007: CEA takes a front seat. ANSYS Advantage, 1 (1): 2.

12. Masuda, M.; Tabata, K., 2000: Analyses of fracture of wood in pinned joints using the finite small area fracture 
criterion and image correlation method, Proceedings of World Conference on Timber Enineering, July 31 - August 3, 2000, Whistler Resort, British Columbia, Canada, p.8, Available at: http://timber.ce.wsu.edu/Resources/papers/toc.pdf

13. Mihulja, G.; Bogner, A.; Župčić, I., 2008: Gluing strength of wood measured with nonstandard pressure-shear method. Wood Research, 53 (1): 91-104.

14. Miyauchi, K.; Masuda, M.; Murata, K., 2006: Analysis of strain distributions of wooden dovetail joints using digital image correlation method. Journal of the Society of Materials Science, Japan, 55 (4): 367-372. http://dx.doi.org/10.2472/jsms.55.367

15. Mihailescu, T., 2003: Finite element analysis of mortise and tenon joint in parametric form. Transilvania University, Faculty of Wood Industry, Brasov, 145 p.

16. Muszyński, L.; Lagaňa, R.; Shaler, S. M., 2002: Optical measurements of wood deformations in changing climate. SEM Annual Conference and Exposition on Experimental and Applied Mechanics - Measurements in Advanced Materials and Systems, $4 \mathrm{p}$.

17. Nicholls, T.; Crisan, R., 2002: Study of the stress-strain state in corner joints and box-type furniture using Finite Element Analysis (FEA). Holz als Roh- und Werkstoff, 60: 66-71. http://dx.doi.org/10.1007/s00107-001-0262-0

18. Nestorović, B.; Skakić, D.; Grbac, I., 2011: Determining the characteristics of composite structure laminae by optical 3D measuremtent of deformation with numerical analysis. Drvna industrija, 62 (3): 193-200.

http://dx.doi.org/10.5552/drind.2011.1103

19. Novotný, M.; Neugebauer, R.; Šimek, M., 2011: Static analysis of an office desk construction. Acta Universitatis Agriculturae et Silviculturae Mendelianae Brunensis. LIX (6): 247-254. http://dx.doi.org/10.11118/actaun201159060247

20. Oh, Y.; Johnson, G.; Gross, M. D.; Do, E. Y. L., 2006: The designosaur and the furniture factory. International Conference on Design Computing and Cognition, Eindhoven, Netherlands, pp. 123-140. http://dx.doi.org/10.1007/978-1-4020-5131-9_7

21. Prekrat, S.; Smardzewski, J., 2010: Effect of gluline shape on strength of mortise and tenon joint. Drvna industrija, 61 (4): 223-228.

22. Prekrat, S.; Smardzewski, J.; Brezović, M.; Pervan, S., 2012: Quality of corner joints of beech chairs under load. Drvna industrija, 63 (3): 205-210.

http://dx.doi.org/10.5552/drind.2012.1220

23. Serrano, E.; Enquist, B., 2010: Assesment of the strain distribution in wood adhesive bonds by contact-free measurement and finite element analyses. Swedish national testing and research institute, Borås, Sweden, p.7.

24. Smardzewski, J., 2004: Modelowanie półsztywnych wezłow konstukcyjnych mebli. Wydawnictwo Akademii Rolnicznej im. Augusta Cieszkowskiego w Poznaniu, p. 224.
25. Smardzewski, J.; Gawroński, T., 2003: Gradient optimisation of skeleton furniture with different connections. Electronic Journal os Polish Agricultureal Universities, 6 (1), Available at: http://www.ejpau.media.pl/volume6/issue $1 /$ wood/abs-01.html

26. Smardzewski, J.; Grbac, I.; Prekrat, S., 2008: Nonlinear mechanics of hyperelastic polyuretane furniture foams. Drvna industrija, 59 (1): 23-28.

27. Smardzewski, J.; Prekrat, S., 2009: Optimisation of a sofa frame in the integrated CAD-CAE environment. Electronic Journal of Polish Agricultureal Universities, 12 (4), Available at:

http://www.ejpau.media.pl/volume12/issue4/abs-01.html

28. Sutton, M. A., 2008: Digital image correlation for shape and deformation measurements. Springer handbook of experimental solid mechanics. Ed. Sharpe, W.N. Springer-Verlag, Heidelberg, pp. 565-600.

29. Sutton, M. A.; Orteu J. J., Schreier, H. W., 2009: Digital image correlation for shape and deformation measurements Basic Concepts, Theory and Applications. Springer Springer-Verlag, Heidelberg, p. 342.

30. Tankut, A. N.; Tankut, N.; Karaman, A., 2012: Creep performance of Ready-to-Assemble (RTA) fasteners in bookcase construction. Proceedings from XXIII. International Conference Ambienta, Zagreb, October 12, 2012, pp. 195-208.

31. Umezaki, E.; Suzuki, T.; Takahashi, M., 2004: Measurement of deformation of wood joints using electronic spackle pattern interferometry. JSME International Journal, Series A, 47 (3): 274-279. http://dx.doi.org/10.1299/jsmea.47.274

32. Weyrauch, A.; Scheffler, M.; Kröppelin, U., 2013: Comparison of test methods for furniture corner connections. Proceedings of the XXVIth International Conference Research for Furniture Industry, Faculty of Wood Technology, Poznań University of Life Science, September 20, 2013, Poland, p. 7. http://furnituredesign.pl/publications

33. *** 2013: EN 1728 Furniture - Seating furniture - Testing methods for the determination of strength and Durability.

34. *** 2010: Wood handbook - Wood as an Engineering Material, Centennial edition. USDA Forest Service FPL, Madison, p. 509.

\section{Corresponding address:}

Ing. MILAN ŠIMEK, Ph.D.

Department of Furniture, Design and Habitation Faculty of Forestry and Wood Technology

Mendel University in Brno

Zemědělská 3

61300 Brno, CZECH REPUBLIC

e-mail: simek@mendelu.cz 